\title{
Cocaine Inhibits GABA Release in the VTA through Endogenous 5-HT
}

\author{
Donald L. Cameron and John T. Williams \\ Vollum Institute for Advanced Biomedical Research, Oregon Health Sciences University, Portland, Oregon 97201
}

The ventral tegmental area (VTA) is thought to be involved in the addictive properties of many drugs, including cocaine. It has been hypothesized that cocaine exerts its actions in the VTA by blocking the reuptake of dopamine released from the dendrites of the $\mathbf{A} 10$ dopamine neurons, thus prolonging the actions of dopamine at D2 autoreceptors. However, cocaine also blocks the reuptake of the other monoamines, including serotonin (5-HT). Using intracellular recordings from midbrain dopamine neurons in a brain slice preparation, we have found that cocaine $(0.1-10 \mu \mathrm{m})$ inhibited the $\mathrm{GABA}_{\mathrm{B}}$ IPSP in a dose-dependent manner. This effect was observed in the presence of the $\mathrm{D} 2$ dopamine receptor antagonists sulpiride $(1 \mu \mathrm{M})$ and eticlopride $(0.1 \mu \mathrm{M}) .5-\mathrm{HT}$ mimicked this effect, as did the selective $5-\mathrm{HT}_{10}$ receptor agonist sumatriptan and the 5-HT-releasing agent fenfluramine. The actions of both 5-HT and cocaine were attenuated by the 5-HT $\mathrm{TCl}_{\mathrm{C}}$ D antagonist metergoline. Pretreatment of slices with the 5-HT-depleting agent $p$-chloroamphetamine (pCA; $10 \mu \mathrm{M}$ )

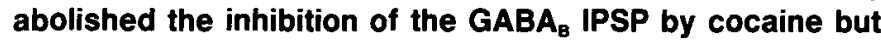
failed to affect the actions of sumatriptan. We conclude that cocaine acts to modulate the GABA input to A10 dopamine neurons via inhibition of the 5-HT transporter, increasing the concentration of 5-HT at presynaptic 5- $\mathrm{HT}_{10}$ receptors. These actions of cocaine were apparent at lower concentrations than those required to act via inhibition of the dopamine transporter. This reduction of inhibitory synaptic input into the VTA would be expected to attenuate the GABA-mediated feedback inhibition from the nucleus accumbens, thus leading to increased activation of dopamine neurons.

[Key words: ventral tegmental area, 5-HT, cocaine, dopamine, GABA, GABA, guinea pigl

Dopamine neurons in the ventral tegmental (VTA) that project to the nucleus accumbens and the prefrontal cortex are thought to mediate the rewarding actions of cocaine (Fibiger, 1978; Roberts and Koob, 1982; Wise, 1984; Koob and Bloom, 1988). The actions of cocaine, in particular, have been examined in this area, where it is thought to act by blocking the reuptake of the dopamine released from dendrites of spontaneously active dopamine neurons. Dopamine released in this manner has been shown to interact with dopamine D2 autoreceptors to hyper-

Received Feb. 24, 1994; revised Apr. 25, 1994; accepted May 5, 1994

We thank Drs. T. V. Dunwiddie and S. W. Johnson for helpful discussions on the work and manuscript. This work was supported by NIH Grants DA00141 and DA04523 to J.T.W. and an NH\&MRC C. J. Martin Fellowship to D.L.C.

Correspondence should be addressed to Dr. J. T. Williams, Vollum Institute for Advanced Biomedical Research Oregon, Health Sciences University, L-474, 3181 SW Sam Jackson Park Road, Portland, OR 97201.

Copyright (C) 1994 Society for Neuroscience $0270-6474 / 94 / 146763-05 \$ 05.00 / 0$ polarize the cells and slow or stop spontaneous firing (Mercuri et al., 1989; Brodie and Dunwiddie, 1990; Lacey et al., 1990). However, these effects are observed at relatively high concentrations of cocaine that may exceed those obtained during "recreational" use by humans (Javaid et al., 1978).

Cocaine also blocks the reuptake of other monoamines, including serotonin (5-HT), for whose transporter it has a higher affinity than for the dopamine transporter (Ritz et al., 1987). The VTA receives a dense 5-HT innervation from the median and dorsal raphe (DR) (Conrad et al., 1974; Azmitia and Segal, 1978), and 5-HT can act presynaptically on the GABA terminals from the forebrain. Johnson et al. (1992) have shown that 5-HT inhibits the release of GABA from these afferents in the brain slice preparation, where a reduction in the evoked $\mathrm{GABA}_{\mathrm{B}}$ IPSP was observed. This inhibition was demonstrated to be mediated by the $5-\mathrm{HT}_{1 \mathrm{~B}}$ receptor and was selective for the GABA $\mathrm{B}_{\mathrm{B}}$ IPSP; that is, no modulation of $\mathrm{GABA}_{A}$ synaptic potentials was observed.

A role for 5-HT in the behavioral actions of cocaine has been implied, although a consistent picture has yet to emerge (Fibiger et al., 1992). Given the anatomical and electrophysiological precedents, it is possible that the actions of cocaine in the VTA may involve an interaction between $5-\mathrm{HT}$ effects and dopamine effects. Thus, the aim of this study was to examine the acute actions of cocaine on the evoked $\mathrm{GABA}_{B}$ synaptic potential recorded from dopamine neurons in the VTA.

\section{Materials and Methods}

Intracellular recordings. Recordings of membrane potential were made from neurons in horizontal slices of guinea pig midbrain. This method has been described previously (Williams et al., 1984). Briefly, guinea pigs $(300-400 \mathrm{gm})$ were anesthetized with halothane and killed. The brain was subsequently removed and the midbrain sliced $(300 \mu \mathrm{m})$ in the horizontal plane using a vibratome. The slice containing the VTA was placed in a recording chamber and superfused $(1.5 \mathrm{ml} / \mathrm{min})$ with warmed $\left(35^{\circ} \mathrm{C}\right) \mathrm{Krebs} /$ bicarbonate buffer containing the following (in mM): $\mathrm{NaCl}, 126 ; \mathrm{KCl}, 2.5 ; \mathrm{NaH}_{2} \mathrm{PO}_{4}, 1.2 ; \mathrm{MgCl}_{2}, 1.2 ; \mathrm{CaCl}_{2}, 2.4$; glucose, $11 ; \mathrm{NaHCO}_{3}, 21.4$; saturated with $95 \% \mathrm{O}_{2}, 5 \% \mathrm{CO}_{2}$. Recordings were made from the portion of the VTA lying between, and rostral to, the interpeduncular fossa (IPF) and the medial terminal nucleus of the accessory optic tract (MT) (Paxinos and Watson, 1986). Recordings were made with $\mathrm{KCl}(2 \mathrm{M}$ )-filled glass microelectrodes (20-50 M $)$ using standard techniques. Bipolar tungsten stimulating electrodes were placed mediocaudal and rostral to the MT. In order to evoke synaptic potentials, neurons were maintained at a membrane potential of -60 to -65 $\mathrm{mV}$ by injecting hyperpolarizing current $(10-20 \mathrm{pA})$ and a train of stimuli ( $500 \mu \mathrm{sec}$ at $70 \mathrm{~Hz}$ for $143 \mathrm{msec}$, i.e., 10 stimuli) ranging from 0.5 to $1.5 \mathrm{~mA}$ were delivered at $90 \mathrm{sec}$ interval using a constant-current stimulation unit (WECO SC-100).

Drug application. Drugs were applied in known concentrations to the superfusion medium. In experiments examining the $\mathrm{GABA}_{B}$ synaptic potential, the superfusion medium contained 2-amino-5-phosphonopentanoic acid (AP5; $100 \mu \mathrm{M}$ ), 6-cyano-2,3-dihydroxy-7-nitroquinox- 

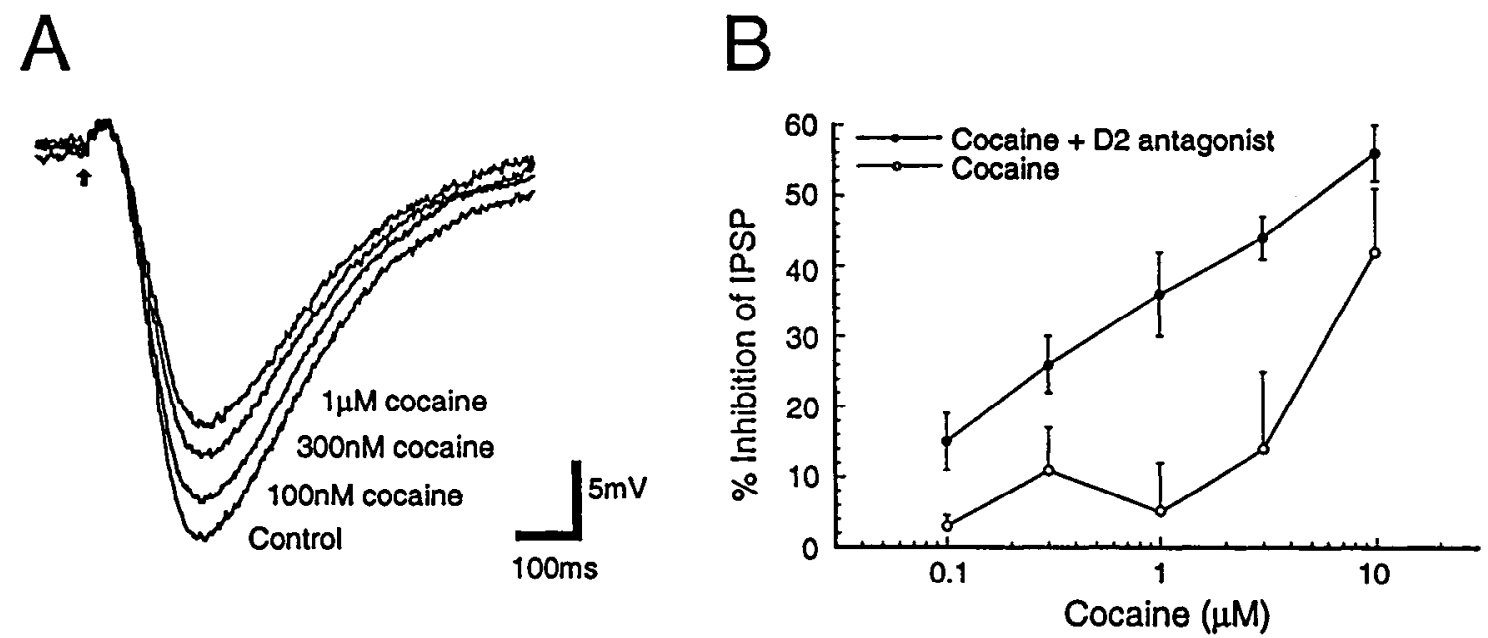

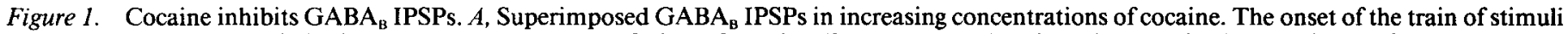
used to evoke the IPSPs is indicated by the arrow. Superfusion of cocaine (0.1-1 $\mu \mathrm{M})$ resulted in a decrease in the amplitude of the IPSP. Each

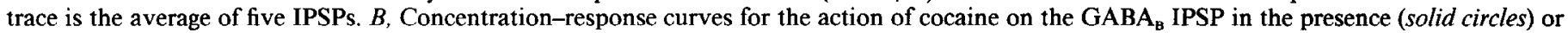
absence (open circles) of a dopamine D2 receptor antagonist [eticlopride (100 nM) or sulpiride (1 $\mu \mathrm{M})$ ]. Each point is the mean of experiments from three to seven cells and is given \pm SEM.

aline (CNQX; $10 \mu \mathrm{M})$, and picrotoxin $(100 \mu \mathrm{M})$ to block fast NMDA-, AMPA-, and $\mathrm{GABA}_{\mathrm{A}}$-mediated synaptic potentials, respectively. In all experiments, either sulpiride $(1 \mu \mathrm{M})$ or eticlopride (100 nM) was included in the superfusion solution to block any possible effect mediated by the dopamine D2 receptor. Cocaine, AP5, picrotoxin, Met-enkephalin, fenfluramine, para-chloroamphetamine (pCA), and 5-hydroxytryptamine (5-HT) were obtained from the Sigma Chemical Company. Baclofen, saclofen, CNQX, eticlopride, and sulpiride were obtained from Research Biochemicals International. Metergoline was a gift from Farmitalia Carlo Erba and CGP35348 was a gift from Ciba Geigy, Basel.

Data analysis. Measurement of membrane potential was made with an Axoclamp-2A amplifier and recorded directly to computer disk using pCLAMP and AXOTAPE software. Data was subsequently analyzed using AXOGRAPH (Axon Instruments Inc.). Values for the time constant of decay $(t)$ were derived from fitting a single exponential curve to the decay phase of the evoked IPSP. Concentration-response curves derived using a Levenberg-Marquardt algorithm to fit a weighted logistic function (KALEIDAGRAPH, Synergy Software). Statistical significance was determined by Wilcoxon signed rank test for related samples and the Kruskal-Wallace test for multiple independent samples. A $p$ value of less than 0.05 was taken as indicating statistical significance.

\section{Results}

Dopamine neurons were identified by their distinctive membrane characteristics and hyperpolarizing response to dopamine but not enkephalin (Johnson and North, 1992).

Characterization of $G A B A_{B} I P S P$. Upon stimulating the slice, a suite of synaptic potentials was evoked. The GABA $_{B}$ IPSP was isolated by blocking $\mathrm{GABA}_{\mathrm{A}^{-}}$and glutamate- (AMPA, NMDA) mediated synaptic potentials with picrotoxin, CNQX, and AP5, respectively. The remaining slow $\mathrm{GABA}_{\mathrm{B}}$ IPSP was blocked by either of the $\mathrm{GABA}_{\mathrm{B}}$ antagonists saclofen $(300 \mu \mathrm{M})$ or CGP35348 $(100 \mu \mathrm{M})$ (data not shown).

Cocaine inhibits the $G A B A_{B} I P S P$. When cocaine $(0.1-10 \mu \mathrm{M})$ was applied to the superfusion medium, the amplitude of the $\mathrm{GABA}_{\mathrm{B}}$ IPSP was decreased in a dose-dependent manner (Fig. $1 A$ ). In the absence of any D2 antagonist in the superfusion medium, the inhibition effect was small and variable at concentrations lower than $3 \mu \mathrm{M}$. The inhibition of the IPSP increased dramatically at higher concentrations. Occasionally, a small increase in amplitude was observed. In the presence of the D2 antagonists eticlopride or sulpiride, however, the atten- uating action of cocaine was consistently observed at lower concentrations (Fig. $1 B$ ). No change in the time course of the IPSP was observed, and cocaine had no effect on resting membrane potential.

$5-H T_{1 D}$ receptor agonists and antagonist modulate the $G A B A_{B}$ IPSP. Both 5-HT $(0.1-100 \mu \mathrm{M})$ and the selective 5-HT ${ }_{1 \mathrm{D}}$ agonist sumatriptan $(0.01-10 \mu \mathrm{M})$ mimicked the actions of cocaine. Sumatriptan was approximately 10 -fold more potent than $5-\mathrm{HT}$, with the $\mathrm{EC}_{50}$ values for 5-HT and sumatriptan being $1.9 \pm 0.3$ $\mu \mathrm{M}$ and $0.16 \pm 0.03 \mu \mathrm{M}$, respectively (Fig. 2). The maximal inhibition of the IPSP was $82.5 \pm 4.4 \%$ in the case of $5-\mathrm{HT}$ and $60.8 \pm 4.3 \%$ in the case of sumatriptan. A small depolarization of the resting membrane potential was often observed when 5 -HT $(10 \mu \mathrm{M})$ was applied to the bath $(2.9 \pm 0.4 \mathrm{mV}, n$ $=7)$. This effect was never observed with sumatriptan. The inhibition of the IPSP by both cocaine ( $3 \mu \mathrm{M})$ and 5 -HT $(10 \mu \mathrm{M})$ was attenuated by the nonselective $5-\mathrm{HT}_{1 \mathrm{C}} / 5-\mathrm{HT}_{\mathrm{ID}}$ receptor antagonist metergoline $(1 \mu \mathrm{M})$. This concentration of metergoline was chosen as higher concentrations were observed to inhibit the IPSP directly (data not shown). At the concentration employed, there was no effect on the amplitude or time course of the IPSP. The opioid agonist [Met $\left.{ }^{5}\right]$-enkephalin (ME) has also been shown to exert presynaptic inhibition on the GABA IPSP (Johnson and North, 1992). Thus, to rule out the possibility that metergoline was having nonspecific effects, we tested the effects of $\mathrm{ME}(10 \mu \mathrm{M})$ in the presence and absence of metergoline. Metcrgoline failed to attenuate the actions of ME (Fig. 2).

The actions of cocaine and 5-HT are presynaptic. Two experiments were done to determine the site of cocaine action. First, when the $\mathrm{GABA}_{\mathrm{B}}$ agonist baclofen $(3 \mu \mathrm{M})$ was applied directly in the superfusion medium, a membrane hyperpolarization ensued $(12.3 \pm 2.6 \mathrm{mV}, n=7)$. This concentration of baclofen was chosen as it induced a submaximal hyperpolarization. Preliminary results indicate the maximal hyperpolarization was obtained at a concentration of $30 \mu \mathrm{M}$ baclofen (data not shown). These observations are similar to those found in substantia nigra neurons, where the $\mathrm{EC}_{50}$ for baclofen was 3.6 $\mu_{\mathbf{M}}$ (Seabrook et al., 1990). The response to baclofen was unaltered by either 5 -HT $(10 \mu \mathrm{M} ; 98 \pm 5 \%$ of control hyperpolar- 
A

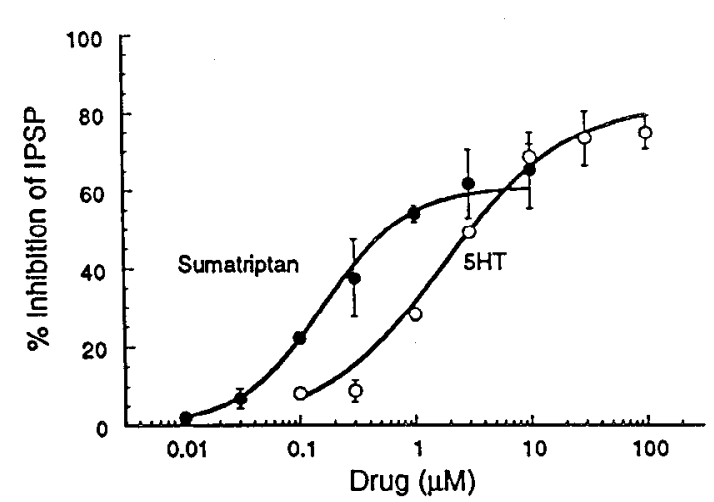

B

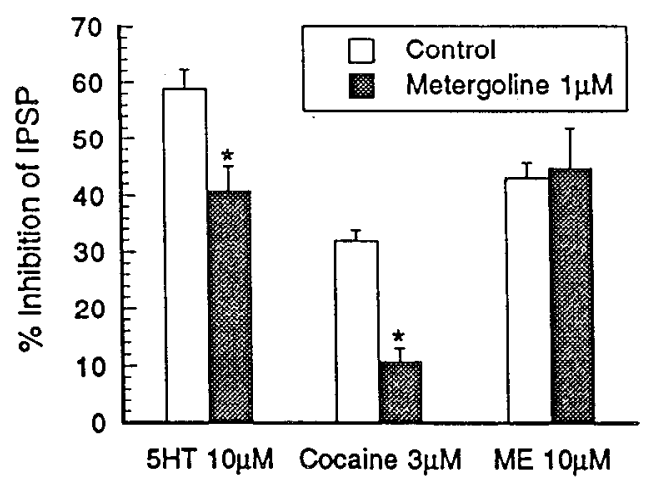

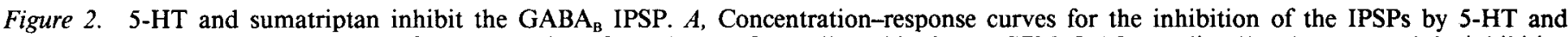
sumatriptan. Each point is the mean of results obtaincd from three to four cells and is given \pm SEM. $B$, Metergoline (1 $\mu \mathrm{M})$ attenuated the inhibiting actions of $5-\mathrm{HT}(10 \mu \mathrm{M})$ and cocaine $(3 \mu \mathrm{M})$, but failed to alter the actions of met-enkephalin (ME, $10 \mu \mathrm{M})$. Each bar is the mean \pm SEM of results from four cells. ${ }^{*}, p<0.05$, Kruskal-Wallace test.

ization, $n=7$ ) or cocaine ( $3 \mu \mathrm{M} ; 97 \pm 3 \%$ of control hyperpolarization, $n=4)$. Second, GABA ${ }_{\mathrm{B}}$ IPSPs exhibit paired-pulse depression in the VTA as has been found in the hippocampus (Davies et al., 1990). That is, when two IPSPs are induced 1.3 sec apart, the second IPSP was smaller than the first. It is presumed that the GABA released during the first IPSP inhibits subsequent release via presynaptic autoreceptors. If a compound changes the ratio between the first and second IPSPs, then this indicates a presynaptic site of action (Davies et al., 1990). Under control conditions, the paired-pulse ratio was $0.89 \pm 0.02(n=$ 11). Both 5-HT (10 $\mu \mathrm{M}, n-6$; Fig. 3) and cocaine ( $3 \mu \mathrm{M}, n=$ 5) significantly increased the paired pulse ratio to $1.02 \pm 0.05$ and $0.96 \pm 0.05$, respectively $(p<0.05$, Wilcoxon signed rank test). That is, both compounds decreased the paired-pulse depression, as illustrated in Figure 3 (scaled).

The actions of cocaine are mimicked by a 5-HT-releasing agent. The 5-HT-releasing agent fenfluramine (Gobbi et al., 1992) mimicked the actions of cocaine (Fig. 4A). A concentration of $10 \mu \mathrm{M}$ significantly reduced the IPSP by an average of $47.7 \pm 5.6 \%(n=5)$. The inhibition took about $20 \mathrm{~min}$ to develop and washed out after approximately $30-40 \mathrm{~min}$.

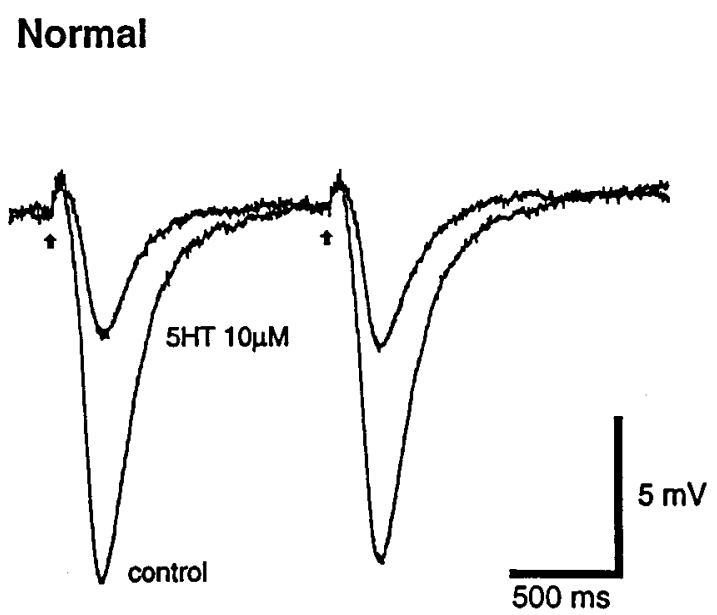

The actions of cocaine are blocked by a 5-HT-depleting agent. When slices were preincubated for 2-4 hr with the 5-HT-depleting agent $p$-chloroamphetamine (pCA; $10 \mu \mathrm{M})$ (Berger et al., 1989; Champney and Matthews, 1991), cocaine $(3 \mu \mathrm{M})$ failed to inhibit the $\mathrm{GABA}_{\mathrm{B}}$ IPSP. This is in contrast to the direct agonist effects of sumatriptan $(0.3$ and $1.0 \mu \mathrm{M})$, which inhibited the IPSP with similar potency to that observed in untreated slices (Fig. $4 B$ ). This latter observation confirms that pCA was not having any direct antagonist effects on the $5-\mathrm{HT}_{1 \mathrm{D}}$ receptor.

\section{Discussion}

Cocaine inhibits the GABA ${ }_{B} I P S P$ presynaptically via 5-HT. The major finding of this study is that cocaine inhibits the $\mathrm{GABA}_{\mathrm{B}}$ IPSP recorded from dopamine neurons in the VTA via a presynaptic mechanism. Further, we have characterized this effect as being mediated by 5-HT. This effect is small and variable in the presence of endogenous dopamine, but the inclusion of a D2 antagonist in the superfusion medium appeared to "unmask" the actions of 5-HT. In support of the presynaptic locus of action of 5-HT and cocaine was the finding that neither of these compounds affected the direct actions of the $\mathrm{GABA}_{\mathrm{B}}$ ag-

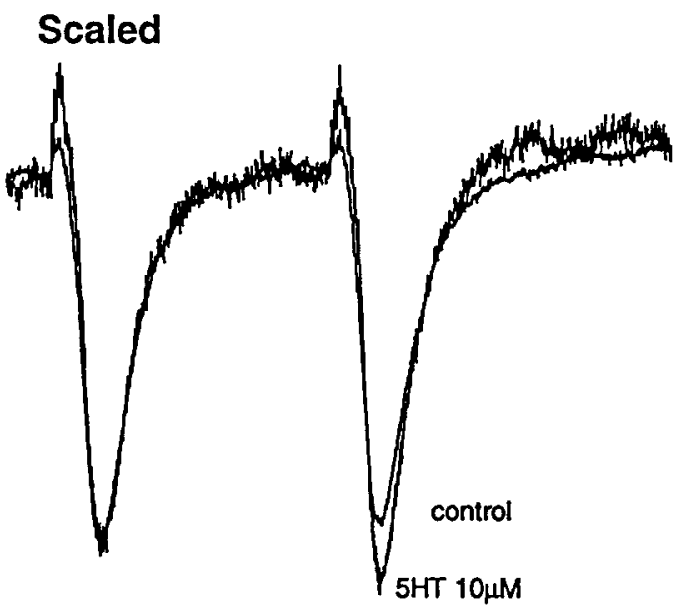

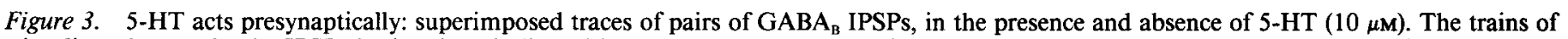
stimuli used to evoke the IPSPs begin where indicated by the arrows and were delivered $1.3 \mathrm{sec}$ apart. Each trace is the average of 5 IPSPs. The right trace is a duplicate of the left trace, except that the IPSP under 5-HT has been scaled such that the first IPSP is the same size as the first control IPSP. 

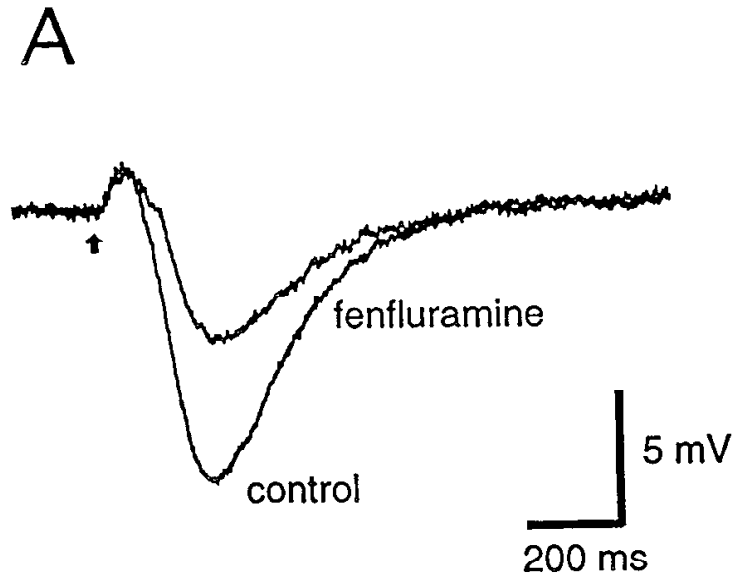

B

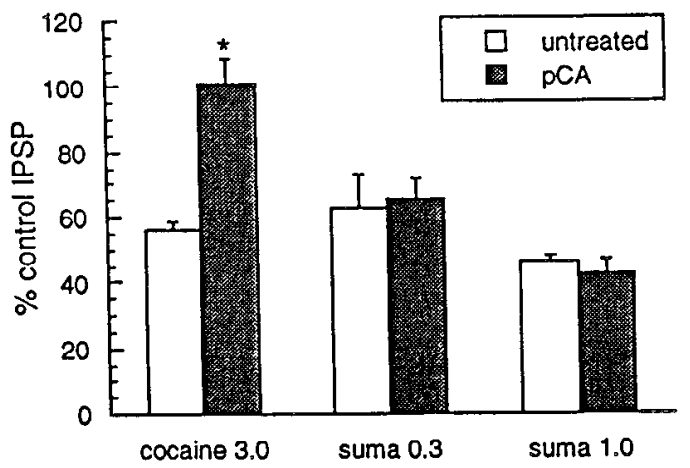

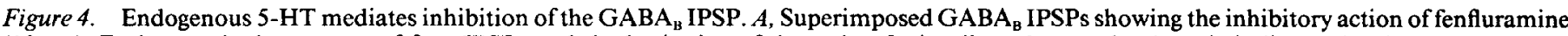
$(10 \mu \mathrm{M})$. Each trace is the average of four IPSPs and the beginning of the train of stimuli used to evoke them is indicated by the arrow. $B$, The

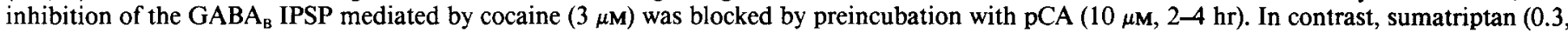
$1.0 \mu \mathrm{m}$ )-induced inhibition of the IPSP was not changed by pretreatment with pCA. Each bar represents the mean \pm SEM of three to four experiments. ${ }^{*}, p<0.05$, Kruskal-Wallace test.

onist baclofen. Additionally, using a paired-pulse paradigm, we found that both 5-HT and cocaine increased the ratio of the second pulse to the first. This observation is consistent with a presynaptically mediated inhibition (Davies et al., 1990). The involvement of endogenous 5-HT was supported by the observations that (1) the 5-HT-releasing agent fenfluramine also in-

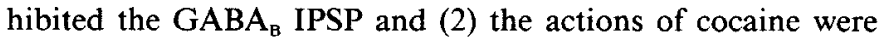
abolished by the $5 \mathrm{HT}$-depleting agent pCA.

In the in vitro slice preparation, dopamine neurons retain their spontaneous activity. However, the cell bodies that give rise to the 5-HT terminals that release 5-HT on to the GABA terminals have been severed. Thus, the actions of cocaine on the 5-HTmediated inhibition of GABA release will be more dependent on stimulation of the afferents arising in the DR. Studies in vivo have shown that 5 -HT neurons in the DR are tonically active (Baraban et al., 1978). Thus, one may expect that under normal conditions, 5-HT is being released in the terminal fields of the DR such as the VTA.

The effect of cocaine on VTA dopamine neurons will also depend on the activity of the descending GABA innervation from the forebrain. Extracellular recording studies in the VTA in vivo have shown that cocaine causes an inhibition of cell firing that is reversible by $D 2$ receptor antagonists (White et al., 1987; Brodie and Dunwiddie, 1990). In contrast, the findings of the present study show that cocaine, acting via $5-\mathrm{HT}$, can inhibit the release of GABA onto VTA dopamine neurons, which would be expected to mediate a disinhibition of these cells. A possible reason that this has not been observed in vivo is that under the anesthetic conditions employed for these experiments, the GABA innervation from the forebrain may be quiescent. Indeed, Guan and McBride (1988) demonstrated that microinfusion of 5-HT into the VTA of conscious, unrestrained rats resulted in an excitation of mesoaccumbens dopamine neurons that was mediated via $5-\mathrm{HT}_{1 \mathrm{~B}}$ receptors. Similar experiments with both locally and systemically applied cocaine are necessary to determine the contribution of both dopamine and 5-HT "components" to the net effect of cocaine in this complex system.

The actions of cocaine and 5-HT are mediated through 5-HT receptors. Johnson et al. (1992) demonstrated that the presyn- aptic inhibition of $\mathrm{GABA}$ release by $5-\mathrm{HT}$ in the rat was mediated via $5-\mathrm{HT}_{1 \mathrm{~B}}$ receptors. In common with humans, the guinea pig homolog of the $5-\mathrm{HT}_{\mathrm{IB}}$ receptor is the $5-\mathrm{HT}_{1 \mathrm{D}}$ receptor, which is also capable of regulating transmitter release, both as an autoreceptor and as a heteroreceptor (Zifa and Fillion, 1992; del Arco et al., 1993; Maura et al., 1993). Preliminary experiments with the $5-\mathrm{HT}_{1 \mathrm{~B}}$ antagonist cyanopindolol in guinea pig VTA (data not shown) failed to attenuate the actions of 5-HT or cocaine. The selective $5-\mathrm{HT}_{1 \mathrm{D}}$ agonist sumatriptan mimicked the actions of cocaine at lower concentrations than did 5-HT.

Although nonselective, metergoline is one of the few ligands for 5-HT receptors that exhibits reasonable affinity for the $5-\mathrm{HT}_{\text {ID }}$ subtype (Heuring and Peroutka, 1987). The ability of metergoline to attenuate the actions of 5-HT and cocaine further supports the proposal that the presynaptic inhibition observed in this study is mediated by the $1 \mathrm{D}$ subtype.

The actions of cocaine mediated by 5-HT occur at lower concentrations than those mediated by dopamine. The maximum concentrations of cocaine that are achieved during abuse in humans is reported to be in the order of 100-600 nM (Javaid et al., 1978). This should be contrasted with the concentrations of cocaine that are required to initiate dopamine-mediated inhibition of VTA neurons, which are of the order of $1-10 \mu \mathrm{M}$ (Brodie and Dunwiddie, 1990; Lacey et al., 1990). The effects of cocaine mediated by 5-HT observed in this study occur at concentrations an order of magnitude lower than reported for those mediated by dopamine. This is consistent with the relative affinities of cocaine for the 5-HT and dopamine transporters (Ritz et al., 1987). Thus, it may be that under conditions of routine cocaine abuse, the $5-\mathrm{HT}$-mediated effects we have observed may represent a significant component of the actions of cocaine in the VTA. In the experimental paradigm employed in this study, the train of stimuli delivered to the slice to evoke the IPSP also appears to result in a coordinated release of dopamine, which, in the absence of the D2 antagonist, introduces a small dopamine component to IPSP. That dopamine component is enhanced by cocaine, thus masking the 5-HT-mediated inhibition. It is difficult to isolate a pure dopamine-mediated synaptic potential (Johnson and North, 1992), making it difficult to assess the actions of cocaine on such a mechanism. 
In vivo dialysis experiments (Kalivas et al., 1988; Kalivas and Duffy, 1993) have demonstrated that the administration of cocaine leads to an increase in extracellular dopamine concentrations in the VTA. This finding is not incompatible with our results as, even with minimal dopamine transporter antagonism by cocaine, disinhibition of the dopamine neurons might be expected to lead to increased dendritic dopamine release. Our findings also account for the observation that cocaine increases extracellular dopamine concentrations in the nucleus accumbens (DiChiara and Imperato, 1988; Kalivas et al., 1988)-an unexpected result if the major effect of cocaine is to inhibit the afferent dopamine neurons.

Multiple actions of cocaine. The GAB $\Lambda$ terminals arising from the forebrain are the site of extensive presynaptic modulation. In addition to 5-HT, opioids also inhibit the release of GABA (Johnson and North, 1992), while dopamine acting at D1 re-

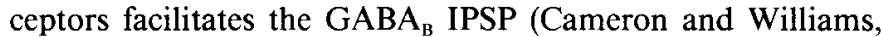
1993). Thus, the net effect of cocaine will depend on the concentration. For example, at low concentrations $(<100 \mathrm{~nm})$, the 5-HT-mediated inhibition of GABA release, and disinhibition of the Al0 neurons, would be expected to predominate. At higher concentrations of cocaine, inhibition of A10 neurons would be the dominant effect through two mechanisms. First, increased extracellular dopamine would serve to hyperpolarize A10 neurons via D2 autoreceptors and second, activation of D1 receptors would oppose the inhibition of the $\mathrm{GABA}_{\mathrm{B}}$ IPSP by 5 -HT.

In summary, the results of this study suggest that cocaine acts to inhibit the release of GABA in the VTA. This occurs via an action of cocaine causing 5- $\mathrm{HT}$ to act at the presynaptic 5- $\mathrm{HT}_{1 \mathrm{D}}$ receptor subtype. Further, this effect of cocaine occurs at concentrations that are lower than those required to induce dopamine-mediated effects in the VTA. Thus, an indirect modulation of VTA dopamine neurons via 5-HT and GABA effecting a neuronal disinhibition may play a role in the acute behavioral effects of cocaine.

\section{References}

Azmitia EC, Segal M (1978) An autoradiographic analysis of the differential ascending projections of the dorsal and median raphe nuclei in the rat. J Comp Neurol 179:641-668.

Baraban JM, Wang RY, Aghajanian G (1978) Reserpine suppression of dorsal raphe neuronal firing: mediation by adrenergic system. Eur J Pharmacol 52:27-36.

Berger UV, Grzanna R, Molliver ME (1989) Depletion of serotonin using $p$-chlorophenylalanine (PCPA) and reserpine protects against the neurotoxic effects of $p$-chloroamphetamine (PCA) in the brain. Exp Neurol 103:111-115.

Brodie MS, Dunwiddie TV (1990) Cocaine effects in the ventral tegmental area: evidence for an indirect dopaminergic mechanism of action. Naunyn Schmiedebergs Arch Pharmacol 342:660-665.

Cameron DL, Williams JT (1993) Dopamine D1 receptors facilitate transmitter release. Nature 366:344-347.

Champney TH, Matthews RT (1991) Pineal serotonin is resistant to depletion by serotonergic neurotoxins in rats. J Pineal Res 11:163167.

Conrad L, Leohard C, Pfaff D (1974) Connections of the median and dorsal raphe nuclei in the rat: an autoradiographic and degeneration study. I Comp Neurol 156:179-206.

Davies CH, Davies SN, Collingridge GL (1990) Paired-pulse depression of monosynaptic GABA-mediated inhibitory postsynaptic responses in rat hippocampus. J Physiol (Lond) 424:513-531.

del Arco C, Galende I, Pazos A (1993) Autoradiographic mapping of $5-\mathrm{HT}$, receptors in the guinea-pig brain with particular reference to the $5-\mathrm{HT}_{1 \mathrm{D}}$ receptor sites. Naunyn Schmiedebergs Arch Pharmacol 347:248-256.

DiChiara G, Imperato A (1988) Drugs abused by humans preferentially increase synaptic dopamine concentrations in the mesolimbic system of freely moving rats. Proc Natl Acad Sci USA 85:5274-5278.

Fibiger HC (1978) Drugs and reinforcement mechanisms: a critical review of the catecholamine theory. Annu Rev Pharmacol Toxicol 18:37-56.

Fibiger HC, Phillips AG, Brown EE (1992) The neurobiology of cocaine-induced reinforcement. Ciba Found Symp 166:96-111.

Gobbi M, Frittoli E, Mennini T, Garattini S (1992) Releasing activities of $d$-fenfluramine and fluoxetine on rat hippocampal synaptosomes preloaded with $\left[{ }^{3} \mathrm{H}\right]$ serotonin. Naunyn Schmiedebergs Arch Pharmacol 345:1-6.

Guan X-M, McBride WJ (1988) Serotonin microinfusion into the ventral tegmental area increases accumbens dopamine release. Brain Res Bull 23:541-547.

Heuring RE, Peroutka SJ (1987) Characterization of a novel ${ }^{3} \mathrm{H}-5-$ hydroxytryptamine binding site subtype in bovine brain membranes. J Neurosci 7:894-903.

Javaid JI, Fischman MW, Schuster CR, Dekirmenjian H, Davis JM (1978) Cocaine plasma concentration: relation to physiological and subjective effects in humans. Science 202:227-228.

Johnson SW, North RA (1992a) Opioids cxcitc dopamine neurons by hyperpolarization of local interneurons. J Neurosci 12:483-488.

Johnson SW, North RA (1992b) Two types of neurone in the rat ventral tegmental area and their synaptic inputs. J Physiol (Lond) 450:455-468.

Johnson SW, Mercuri NB, North RA (1992) 5-Hyroxytryptamine ${ }_{1 \mathrm{~B}}$ receptors block the $\mathrm{GABA}_{\mathrm{B}}$ synaptic potential in rat dopamine neurons. J Neurosci 12:2000-2006.

Kalivas PW, Duffy P (1993) Time course of extracellular dopamine and behavioral sensitization to cocaine. II. Dopamine perikarya. J Neurosci 13:276-284.

Kalivas PW, Duffy P, DuMars LA, Skinner C (1988) Behavioral and neurochemical effects of acute and daily cocaine administration in rats. J Pharmacol Exp Ther 245:485-492.

Koob GF, Bloom FE (1988) Cellular and molecular mechanisms of drug dependence. Science 242:715-723.

Lacey MG, Mercuri NB, North RA (1990) Actions of cocaine on rat dopaminergic neurons in vitro. Br J Pharmacol 99:731-735.

Maura G, Thellung S, Andrioli GC, Ruelle A, Raiteri M (1993) Release-regulating serotonin $5-\mathrm{HT}_{1 \mathrm{D}}$ autoreceptors in human cerebral cortex. J Neurochem 60:1179-1182.

Mercuri NB, Calabresi P, Bernardi, G (1989) The mechanism of amphetamine-induced inhibition of rat substantia nigra compacta neurones investigated with intracellular recording in vitro. Br J Pharmacol 98:127-134.

Paxinos G, Watson C (1986) The rat brain in stereotaxic coordinates. Sydney: Academic.

Ritz MC, Lamb RJ, Goldberg SR, Kuhar MJ (1987) Cocaine receptors on dopamine transporters are related to self-administration of cocaine. Science 237:1219-1223.

Roberts DCS, Koob GF (1982) Disruption of cocaine administration following 6-hydroxydopamine lesions of the ventral tegmental area in rats. Pharmacol Biochem Behav 17:901-904.

Seabrook GR, Howson W, Lacey MG (1990) Electrophysiological characterization of potent agonists and antagonists at pre- and postsynaptic $\mathrm{GABA}_{\mathrm{B}}$ receptors on neurones in the rat brain slices. $\mathrm{Br} \mathrm{J}$ Pharmacol 101:949-957.

White FJ, Wachtel SR, Johansen PA, Einhorn LC (1987) Electrophysiological studies of the rat mesoaccumbens dopamine system: focus on dopamine receptor subtypes, interactions, and the effects of cocaine. In: Neurophysiology of dopaminergic systems - current status and clinical perspectives (Chiodo LA, Freeman AS, eds), pp 317365. Chicago: Lakeshore.

Williams JT, North RA, Shefner SA, Nishi S, Egan TM (1984) Membrane properties of rat locus coeruleus neurones. Neuroscience 13: $137-156$.

Wise RA (1984) Neural mechanisms of the reinforcing action of cocaine. Res Monogr NIDA 50:15-33.

Zifa E, Fillion G (1992) 5-Hydroxytryptamine receptors. Pharmacol Rev 44:401-458 